\title{
The influence of Western corn rootworm seed coating and granular insecticides on the seasonal fluctuations of soil nematode communities in a maize field
}

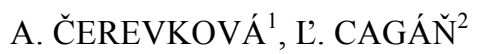 \\ ${ }^{1}$ Institute of Parasitology SAS, Hlinkova 3, 04001 Košice, Slovak Republic, E-mail: cerev@saske.sk; \\ ${ }^{2}$ Slovak Agricultural University, A. Hlinku 2, 94976 Nitra, Slovak Republic, E-mail: ludovit.cagan@gmail.com
}

\begin{abstract}
Summary
Western corn rootworm, Diabrotica virgifera virgifera, is a pest that needs to be controlled with chemicals in the maize monoculture. The aim of this study was to examine the influence of insecticides on nematode communities in a maize field. Four soil treatments were used in this experiment: variant 1 - a granular application with tefluthrin (199.5 g a.i./ha); variant 2 - a granular application with clothianidin (110 g a.i./ha); variant 3 - a seed treatment with clothianidin $(1.25 \mu \mathrm{g}$ a.i/seed); and control - a maize field without insecticides.

During the investigated period, a total of 19117 soil nematode individuals were captured and 9 orders, 33 genera and 37 species were identified. Acrobeloides nanus, Cephalobus persegnis, Eucephalobus striatus and Basiria gracilis were the dominant species, accounting for $48 \%$ of the total number of individuals. The mean abundance and species diversity index were significantly lower for variant 2. Bacterial feeders were the dominant trophic group for all 4 variants. The numbers of nematodes in particular trophic groups (i.e., bacterial feeders, fungal feeders and omnivores) were significantly different between variant 2 and the control. The $\Sigma$ Maturity index, Maturity index and Plant parasitic index did not show significant differences among the variants. The higher values of the Enrichment and Structure indices were observed in the first month of the investigation in all 4 variants. A cluster analysis showed that nematode species population densities were strongly affected by the date of soil sample collection and by the variants used in the experiment.
\end{abstract}

Keywords: Nematodes; Diabrotica; insecticides; soil environment

\section{Introduction}

Western corn rootworm, Diabrotica virgifera virgifera LeConte (Coleoptera: Chrysomelidae), is the most de- structive pest of maize (Zea mays L.) in North America and began to successfully invade Central Europe in the early 1990s (Toepfer \& Kuhlmann, 2004). Seed coating or granular insecticides are the usual methods of soil pest control in maize monoculture, and clothianidin and tefluthrin are often used to control this pest (Pilz et al., 2009).

Before the invasion of $D$. v. virgifera to Slovakia, the chemical control of maize soil pests was only used sporadically because of elaterid larvae. After 2004, the situation had completely changed. In the south of Slovakia the damage caused by D. v. virgifera reached more than $80 \%$ (Cagán̆, 2008) and the behaviour of farmers changed quickly. Farmers observed that they needed to use crop rotation or chemical control. However, many farms grew maize in almost $50 \%$ of their area. Thus, chemical control of D. v. virgifera was an obligation. This issue became an absolutely new situation. Maize culture, which before was almost free from insecticides, started to endanger the environment.

Communities of nematodes are frequently used as suitable bioindicators based on their occurrence in all types of soil, a high abundance and the presence of all trophic groups. Earlier studies on nematodes in maize throughout the world were focused mostly on plant-parasitic nematodes that feed on maize (Bernard et al., 2010; Bowen et al., 2008; Tylka et al., 2011) or the impact of crop rotation on nematode communities (Drake et al., 2010; Manachini et al., 2009; Rahman et al., 2007; Villenave et al., 2009). It was also mentioned that low infections of plant-parasitic nematodes may lead to greater availability of plant nutrients (Yeates et al., 1999). In Slovakia, the structure of nematode communities in maize was studied by Š́ly (1970) and Sabová et al. (1979), but information on the seasonal fluctuations of nematodes in maize is lacking. Similarly, data on the impact of $D$. $v$. virgifera insecticides on nematode populations in maize fields are insufficient. Therefore, the objective of this investigation was to obtain 
information regarding the seasonal fluctuations of nematode populations in maize fields and to determine the impact of chemical treatments on nematode communities.

\section{Materials and methods}

\section{Characteristic of locality and field trial}

The field trial was conducted at Komoča $(47.969,18.022)$ in southwest Slovakia. The site was situated in a warm region with an average of 50 or more summer days annually and a warm and dry sub-region with a mild winter. An average daily temperature in January is higher than $-3^{\circ} \mathrm{C}$ and an average daily temperature in July reaches $20-$ $21^{\circ} \mathrm{C}$. The mean annual precipitation total is $500-550 \mathrm{~mm}$. The location is characterised by calcaric fluvisols associated with gleyic and arenic calcaric fluvisols from carbonate alluvial segments. Soil has a clayey texture (Miklós, 2002). The temperature during the period of investigation (May - September 2011) ranged from $16.7-21.6^{\circ} \mathrm{C}$ and rainfall ranged from $15.4-83.7 \mathrm{~mm}$.

The maize hybrid Realli CS (Caussade Semences) was used in the experiment.

The following variants were used in the trial:

Variant 1: a granular insecticide application into the rows during sowing - Force ${ }^{\mathrm{TM}} 1.5 \mathrm{G}$ (Syngenta) tefluthrin 1.5 $\%, 199.5 \mathrm{~g}$ a.i. $/ \mathrm{ha}=13.3 \mathrm{~kg}$ product $/ \mathrm{ha}$.

Variant 2: a granular insecticide application into the rows during sowing - Santana ${ }^{\mathrm{TM}}$ (Arysta LifeScience) clothianidin $1 \% 110 \mathrm{~g}$ a.i. $/ \mathrm{ha}=11 \mathrm{~kg}$ product $/ \mathrm{ha}$.

Variant 3: a commercially applied seed treatment - Pon- cho $^{\mathrm{TM}} 600$ FS (Bayer CropScience) clothianidin 104 $\mathrm{ml} / 70000$ seeds $($ per hectare $)=1.25 \mu \mathrm{g}$ a.i $/$ seed.

Control variant: a maize field without soil insecticides. Maize was sown on April 27. Sampling was carried out during five months in 2011 on the following dates: May 4, June 8, July 6, August 3 and September 5.

Field trial included four variants randomly arranged in 5 repetitions. Plot size was $100 \mathrm{~m}^{2}$. For each research variant, five bulked samples of soil (one per each plot) were used for investigating nematode communities. A bulked sample consisted of five sub-samples collected at a depth of $15 \mathrm{~cm}$ on the individual sampling dates.

\section{Extraction and identification of nematodes}

Nematodes were isolated from $100 \mathrm{~g}$ of mixed fresh soil samples using the Baermann method, fixed in FAA solution and evaluated on permanent glycerine slides (Southey, 1986). All isolated nematodes were determined to species level and juveniles were determined to the genus level using light microscope Nikon eclipse $90 i$.

\section{Nematode community analysis}

Nematode taxa were assigned to trophic groups according to Yeates et al. (1993). Community indices were calculated as follows: the Shannon-Weaver species diversity index (H'spp) (Shannon \& Weaver, 1949); the Maturity index (MI) and Plant parasite index (PPI) proposed by Bongers (1990); ratio of PPI/MI proposed by Bongers and Korthals (1995); ratio of bacterial feeders and fungal feeders $(\mathrm{B} / \mathrm{F})$ proposed by Wasilewska (1997); the Enrichment index
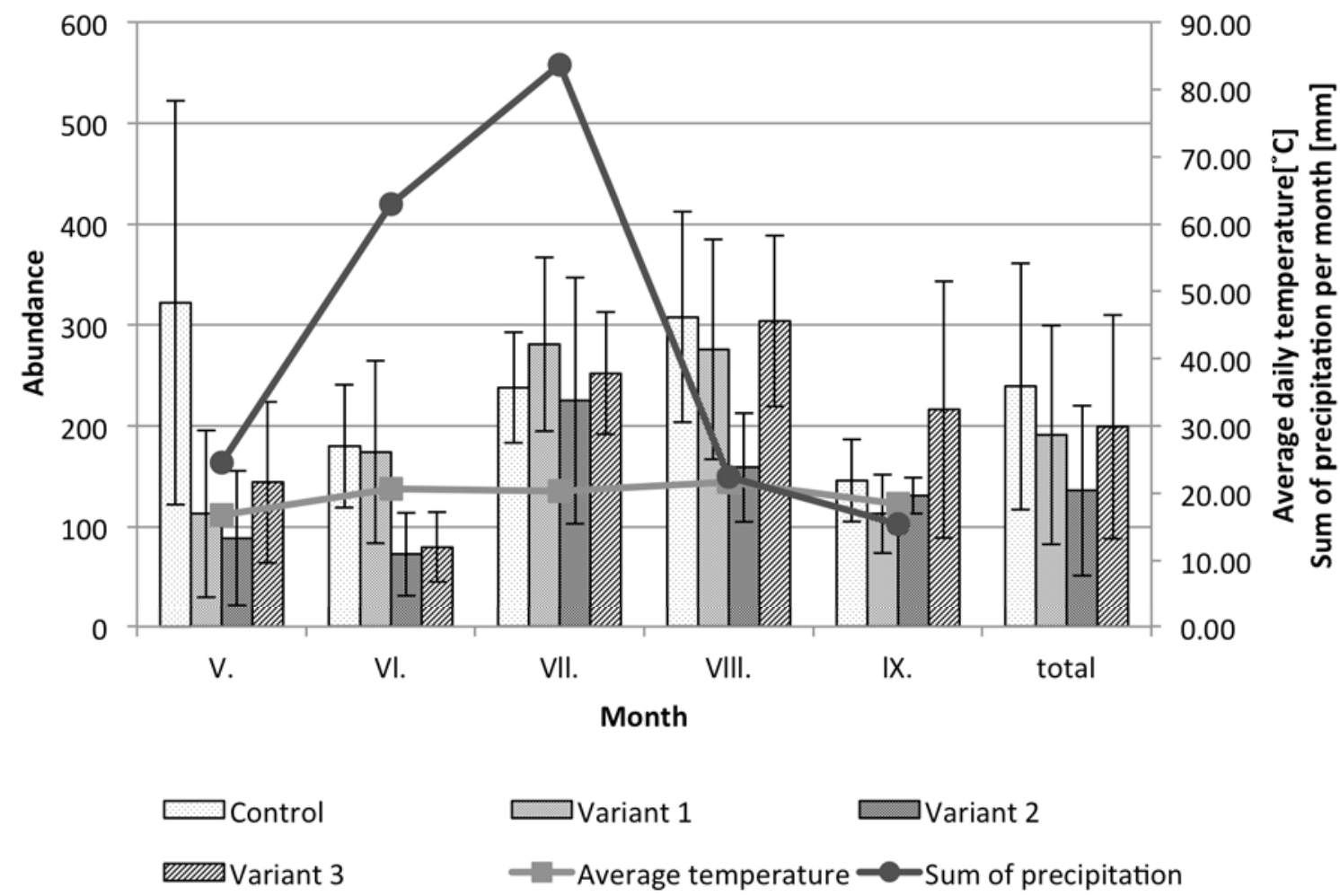

Fig. 1. Abundance of nematodes in $100 \mathrm{~g}$ of soil, calculated for each month from May to September $(n=5)$ and for each variant in total $(n=25)$ at the locality Komoča (Slovakia) during 2011. Variant 1 includes the treatment with tefluthrin and variants 2 and 3 include granular and seed 


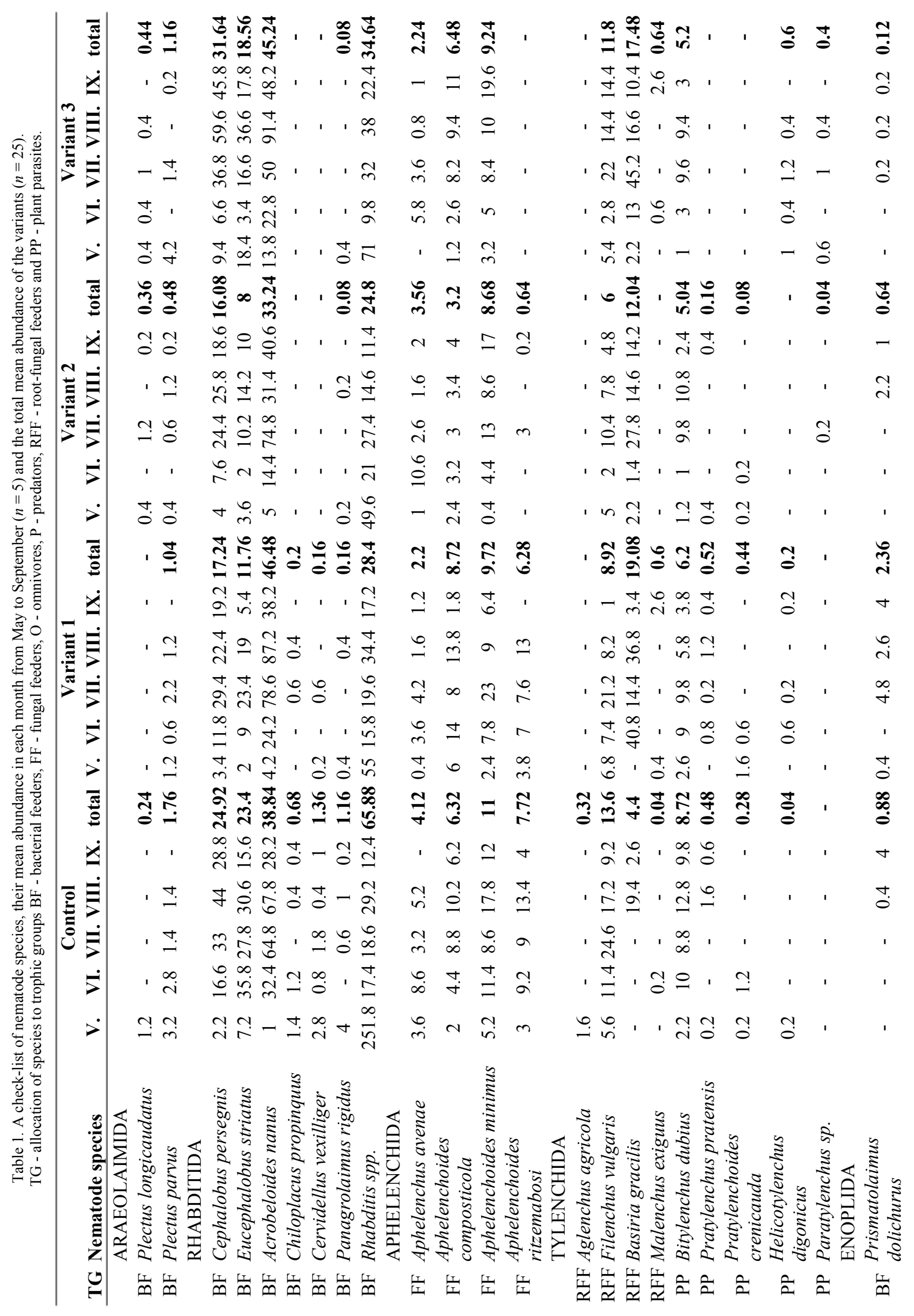




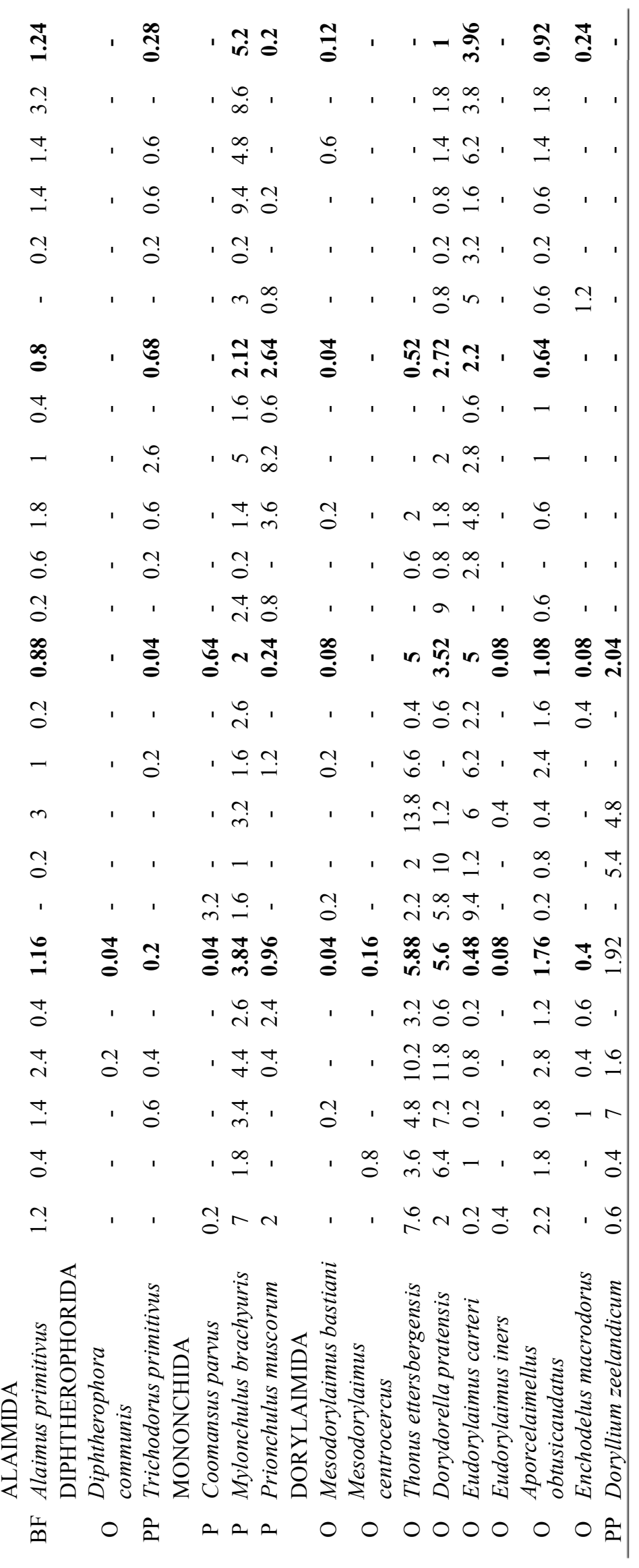


(EI), the Structure index (SI) and the Channel index (CI) according to Ferris et al. (2001) with weightings of nematode taxa as suggested by the authors. The weightings for taxa not included in this study were derived from the c-p values by Bongers (1990). The abundance of nematodes, H'spp, abundance of nematodes in trophic groups, ecological indexes and all other indices were calculated as the mean.

\section{Data analysis}

An analysis of variance was used for statistical analysis; the means were compared by the Tukey's HSD test ( $p>$ $0.05)$. Five repetitions from each variant were used in calculation of difference among four variants. Data from each date and total data were evaluated separately. Programme "Statistica" was used for the calculations (Tables 2 and 3). Cluster analysis was performed by using Ward's method of Euclidean distances (StatSoft, 2001).

\section{Results}

Taxonomical evaluation of nematode communities A total of 37 nematode species and 33 genera, including 7 species of plant parasites, were identified in the maize field during the investigated period. The number of identified species (36) and genera (32) in the control was higher than in variants $1-3(25-32$ species or $24-30$ genera) (Table 1$)$. The total abundance of nematodes was significantly lower in variant 2 (Fig. 1). The highest total abundance of nematodes in the control was mostly caused by a high abundance of Rhabditis spp. in May (also confirmed statistically by an ANOVA and Tukey multiple range test ( $p$ $=0.05$ ). Some species were observed abundantly in the control but occurred with low abundance or did not occur at all in variants with chemical applications. A higher abundance of nematodes in the control and variant 1 were caused by higher abundance of the species Aphelenchoides ritzemabosi, Doryllium zeelandicum and Thonus ettersbergensis, in variants 2 and 3, these nematode species occurred in low abundance. On the other hand, the abundance of Basiria gracilis was significantly higher in variants $1-3$ compared to the control (Table 1). The abundance of nematodes was markedly changed during the season in all variants and higher changes were observed in variant 3 . In the second month after the granular application, variant 3 contained only 80 nematode individuals, however, in August (approximately four months after the granular application), abundance increased to 304 individuals in $100 \mathrm{~g}$ of soil. The least amount of change in abundance during the season was observed in the control and in variant 1 (Fig. 1). Out of a total number of identified nematode species 7 species were obligate plant parasite nematodes. Only two plant parasite species were identified in all investigated variants: Bitylenchus dubius and Trichodorus primitivus (Table 1).
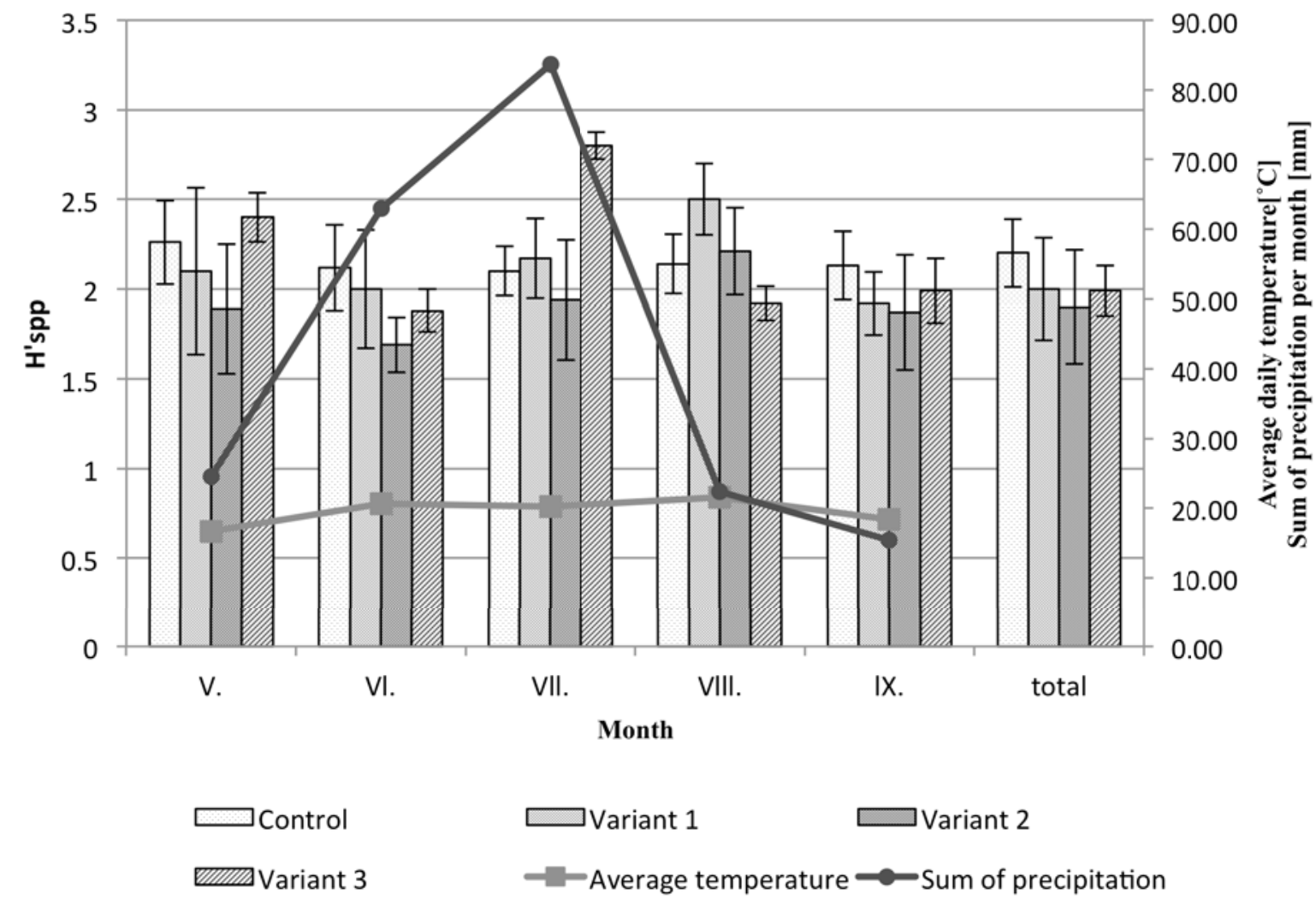

Fig. 2. Shannon-Weaver Diversity Index H'spp, calculated for each month from May to September $(n=5)$ and for each variant in total $(n=25)$. Locality Komoča (Slovakia) during 2011. Variant 1 includes the treatment with tefluthrin and variants 2 and 3 include granular and seed treatments with clothianidin. 


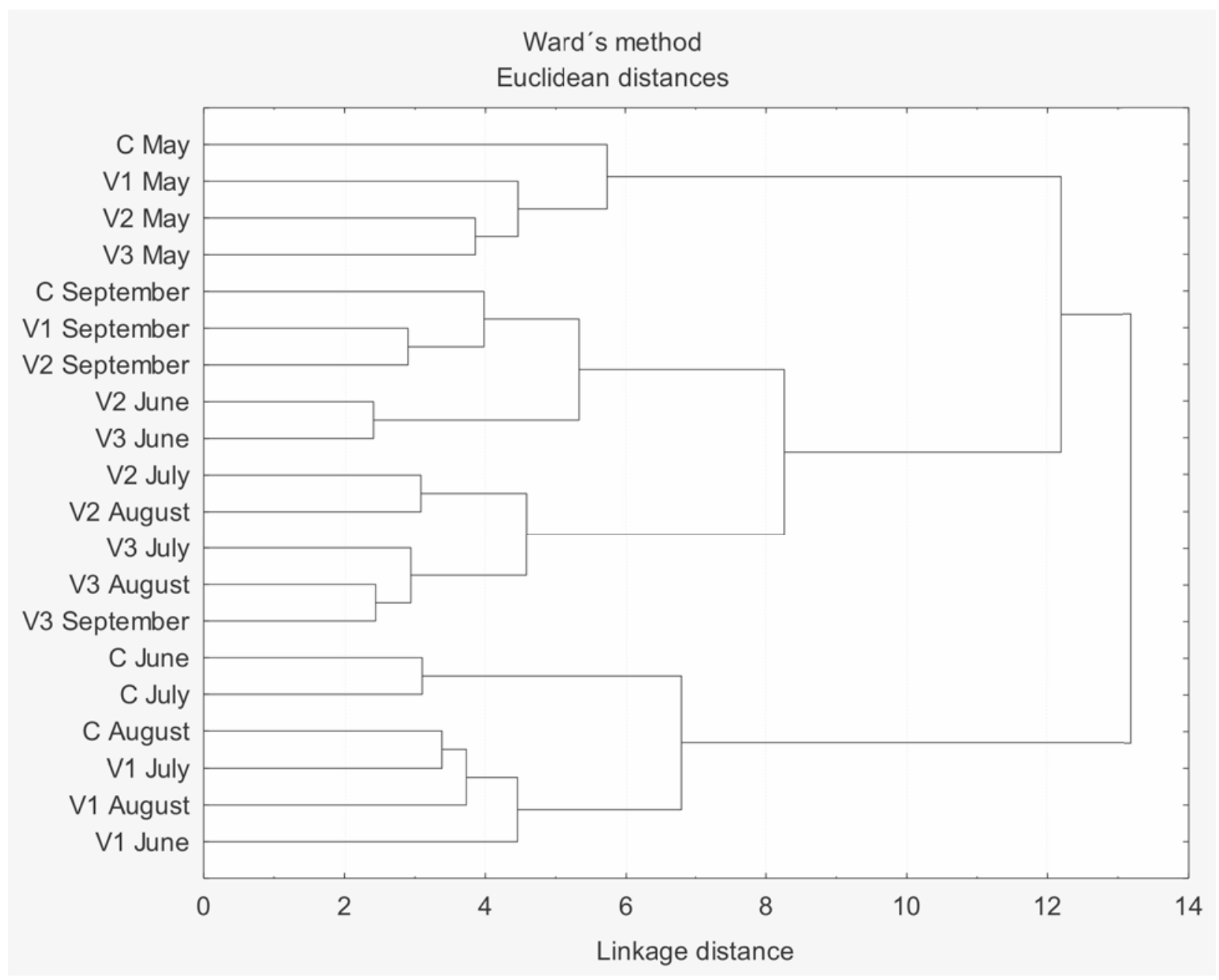

Fig. 3. Cluster analysis of nematode species population densities in a maize field during May to September 2011 in four soil treatments: V1 - variant 1; V2 - variant 2; V3 - variant 3; C - control. Variant 1 includes the treatment with tefluthrin and variants 2 and 3 include granular and seed treatments with clothianidin. Data $\log (\mathrm{x}+1)$ where $\mathrm{x}=$ species population density. Locality Komoča, Slovakia.

\section{Diversity of nematode species}

Values for the diversity index H'spp indicated different species structures of nematode communities. The highest H'spp was recorded in the control. On the other hand, the lowest total H'spp was observed in variant 2, where the significantly lowest total abundance was also observed. When the nematode abundance and the H'spp in variant 2 were compared during season, the lowest values were observed in the second month of the evaluation (Fig. 2).

The cluster analysis of species population densities produced three main clusters: the upper cluster consisted of samples of all four variants collected in May; the lower cluster consisted of samples of the control and variant 1 sampled from June to August. The middle cluster contained two sub-clusters, which consisted of samples of variants 2 and 3 (except for two samples of the control and variant 1 that were collected in September) (Fig. 3).

Ecological evaluation of nematode communities based on trophic groups and ecological indices

Nematode communities were represented by all trophic groups. Bacterial feeders were the dominant trophic groups in all variants, with the lowest significant total abundance in variant 2 (Table 2). Similarly, the lowest total abundance of fungal feeders was observed in variant 2 and the lowest total abundance was observed in omnivores in variants 2 and 3 compared to the control. The change in abundance of plant parasites, root-fungal feeders and predators was small during May-September and significant differences were not observed between variants.

The calculated ecological indices $\Sigma \mathrm{MI}, \mathrm{MI}$, PPI and ratio PPI/MI values, were without significant differences in the variants (Table 3 ). The values of ratio $\mathrm{B} / \mathrm{F}$ and $\mathrm{CI}$ fluctuated across all sampling dates and variants, but no significant differences in these values were observed except for the $\mathrm{CI}$ in variant 2 in June. A significant sampling date effect was observed in the values of the EI and SI. In May, a higher value of the EI and SI was observed in all variants and was caused mainly by a higher abundance of Rhabditis spp. and a lower abundance of Acrobeloides nanus, respectively. Using the EI and SI, most samples were characterised as containing a degraded soil food web with high $\mathrm{C}: \mathrm{N}$ ratios and the decomposition channels were provided by fungi. 

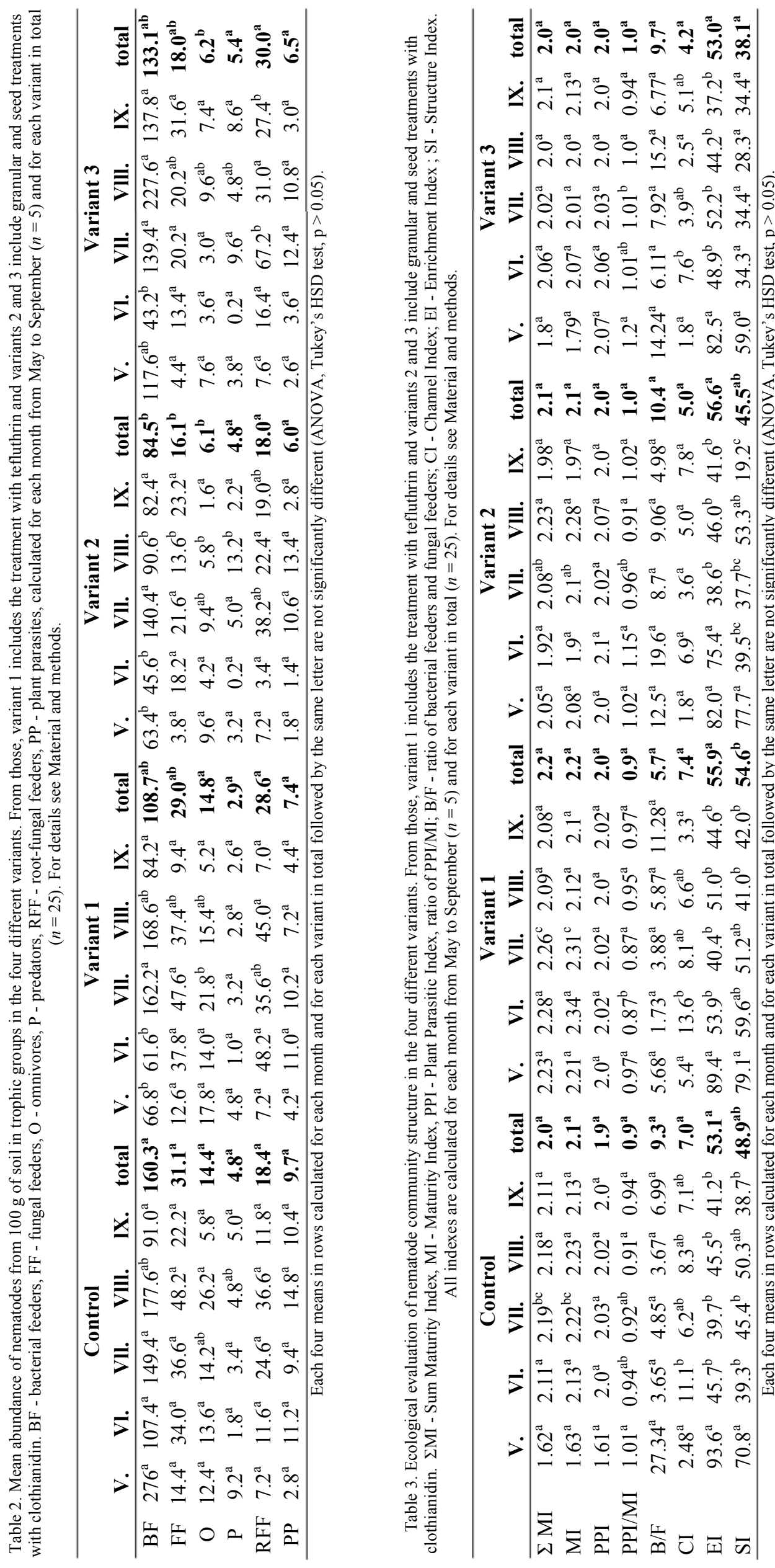


\section{Discussion}

Our study was conducted in a maize field to determine the impact of the season and chemical treatment on nematode communities. The nematode community was investigated for species composition, trophic structure and biodiversity. The findings from a control and three different chemically treated fields of corn were compared. A total of 37 nematode species and 33 genera were identified during the investigated period. This number of species and genera was higher than the number observed by Śály (1970) in maize fields in Slovakia (only 16 species). On the other hand, Landi and Manachini (2005) observed 45 genera in maize fields in Italy.

The total abundance was the highest in the control, mostly caused by a high abundance of Rhabditis in May. These results agree with many authors who recorded higher abundances of nematodes in soils without chemical treatment (JingNan et al., 2010; Waliyar et al., 1992; Zhou et al., 2008) or decreased nematode abundance and diversity with intense land cultivation (Kimenju et al., 2009). In contrast, Brmež et al. (2007) observed higher nematode abundance but a lower number of genera in the agricultural treatments than in the treatment without human investigation. It was also found that nematode species were present in greater numbers on fertilised soils (McIntosh et al., 1999).

In the control and variant 1 (tefluthrin), a higher abundance of the species Aphelenchoides ritzemabosi, Doryllium zeelandicum and Thonus ettersbergensis was observed. However, in variants 2 and 3 (clothianidin), these nematode species occurred in low abundance. It is important to note that the mode of action of tefluthrin and clothianidin is different. Tefluthrin is not transported in the plant from the roots to the leaves, but clothianidin is a systemic insecticide (Bewley et al., 2006; Schmuck \& Keppler, 2003). However, the abundance of Basiria gracilis was significantly higher in variants with an application of chemicals (variants $1-3$ ) compared to the control. We do not have an explanation for this result. B. gracilis was observed in 7 samples (from 25) in the control, in 17 samples in variant 1 and in 25 samples in both variants 2 and 3 .

The decrease in nematode diversity was assessed using the diversity index H'spp and was used to reflect the underlying changes in physical, chemical and biological properties of the soil environment. In all examined variants, nematode diversity was low with a mean $\mathrm{H}$ 'spp value of no more than 2.2 (control). Landi and Manachini (2005) observed a higher level of disturbance in eight maize fields in Italy, where the H'spp value was only 1.08. A comparison of nematode abundance and the H'spp in variant 2 revealed the lowest values in the second month of the evaluation.

The dominant trophic group was the bacterial feeders, and in particular, Rhabditis was the most abundant and, often, the most dominant species. Venette and Ferris (1997) observed an increase of bacterial feeders at higher temperatures. Similar results were observed in maize by Landi and
Manachini (2005) where the genus of bacterial feeders Rhabditis and Acrobeloides together with plant parasites Pratylenchus and Helicotylenchus made up more than $70 \%$ of the total nematode abundance collected. Similarly, the dominant trophic group of bacterial feeders, followed by the plant parasites, was observed by Manachini and Lozzia (2002) in a Bt maize crop and by Brmež et al. (2007) in soils with agricultural treatments. In contrast, Ou et al. (2005) observed bacterial feeders to be the most abundant group in paddy fields, while plant parasites were observed to be the most abundant group in maize fields. Kimenju et al. (2009) observed a predominance of plant parasitic nematodes in soils under agricultural production, while fungal feeder nematodes dominated in forested land. Our results show that in the case of bacterial and fungal feeders, only variant 2 showed significant effects of nematode abundance in these trophic groups. It was observed that treatments in variants 2 and 3 significantly influenced omnivore nematode abundance.

In almost all variants, high densities of the obligate parasite Bitylenchus dubius and root-fungal feeders Filenchus vulgaris were observed. In particular, B. dubius is potentially harmful for maize plants in latitudes of temperate climatic zone. B. dubius frequently occurs in arable soil with various plants, e.g., cereals (Sabová et al., 1979; Šály, 1976) and other plants in arable soils (Š́ly, 1970, 1983). Williams and Beane (1984) consider this species a dangerous maize pest in England. Landi and Manachini (2005) and Khan et al. (2009) observed genera Pratylenchus and Helicotylenchus as dangerous plant parasites of maize. These genera were also recorded in our variants but with low abundance.

The $\Sigma$ Maturity index, Maturity index, Plant parasitic index and ratio PPI/MI values did not show statistically significant differences among the treatments, although their trends served as effective tools. In agricultural soils regularly cultivated and fertilised by organic manures (Lišková \& Renčo, 2007), recorded MI values are similar to those in maize crops with a dominance of bacterial feeder nematodes. This effect may be caused by the addition of organic matter that improves microbial activity in the soil.

The ratio of $\mathrm{B} / \mathrm{F}$ is proposed to be an indicator of decomposition pathways. The Channel index (CI) improves the resolution of $\mathrm{B} / \mathrm{F}$ and indicates the predominant decomposition pathways using selected taxa (Ferris et al., 2001). In our study, significant differences were not observed for the values of $\mathrm{B} / \mathrm{F}$ and $\mathrm{CI}$ among the sampling dates and variants except for the data from June. The highest values of EI and SI were observed in all variants in the first month of the experiment. Berkelmans et al. (2003) reported that a higher SI indicated a well-regulated and healthy ecosystem. Zhang et al. (2010) reported that soil nematode community structure could be influenced by agrochemical application and using SI is a useful indicator to assess the impact of agrochemicals on soil ecosystems.

The application of different chemical treatments for the control of Diabrotica virgifera virgifera in maize showed little impact on the nematofauna, affecting neither species 
composition nor biodiversity. The calculated ecological indexes $\Sigma \mathrm{MI}, \mathrm{MI}$, PPI and PPI/MI values, were without significant differences in the investigated variants (Table 3 ). Only variant 2 caused a significant change in abundance, H'spp and trophic group composition. Bacterial feeders, fungal feeders and omnivores were also less numerous in variant 2 compared to the control. Voeste et al. (2010) mentioned that mixtures with clothianidin show an impact on many nematode species. However, another source (e.g., FAO, Clothianidin, 2010) mentioned that even though clothianidin has a broad spectrum of activity against insects, it shows no efficacy against spider mites and nematodes. In our variant 2 it was used $110 \mathrm{~g}$ a.i./ha, in variant 3 it was used $1.25 \mu \mathrm{g}$ a.i/seed (less than $1 \mathrm{~g}$ a.i./ha). It is probably the reason why only variant 2 caused a significant change in abundance of nematodes. It was confirmed that overuse of pesticides has an effect on the amount and relative abundance of soil nematodes (Zhou et al., 2008). The effect of tefluthrin was not significant, and this result is expected because this chemical is used in combination with entomopathogenic nematodes (Nishimatsu \& Jackson, 1998; Schmuck \& Keppler, 2003).

\section{Acknowledgements}

The authors acknowledge the support of the scientific grant agency VEGA (Grant No. 2/0079/13 and Grant No. 1/0894/11) and Slovak Hydrometeorological Institute for providing the meteorological data.

\section{References}

Berkelmans, R., Ferris, H., Tenuta, M., Van Bruggen, A. H. C. (2003): Effects of long-term crop management on nematode trophic levels other than plant feeders disappear after 1 year of disruptive soil management. Appl. Soil Ecol., 23(3): 223 - 235. DOI: 10.1016/S0929-1393(03)00047-7

Bernard, E. C., Handoo, Z. A., Powers, T. O., Donald, P. A., HeINZ, R. D. (2010): Vittatidera zeaphila (Nematoda Heteroderidae), a new genus and species of cyst nematode parasitic on corn (Zea mays). J. Nematol., 42(2): 139 - 150 Bewley, J. D., Black, M., Halmer, P. (2006): The Encyclopedia of Seeds. Science, Technology and Uses. London, UK: CABI International, $40 \mathrm{pp}$.

BONGERS, T. (1990): The maturity index: an ecological measure of environmental disturbance based on nematode species composition. Oecologia. 83(1): $14-19$

Bongers, T., Korthals, G. (1995): The behaviour of MI and PPI under enriched condition. Nematologica, 41(3): 286

Bowen, K. L., Hagan, A. K., CAMPBell, H. L., NightengaLE, S. (2008): Effect of southern root-knot nematode (Meloidogyne incognita race 3) on corn yields in Alabama. In: Plant Management Network. Retrieved from http://www.plantmana gementnetwork.org/pub/php/research/2008/rootknot/

Brmež, M., IVEzić, M., RASPudić, E., TRIPAR, V., BALIČEVIĆ, R. (2007): Nematode communities as bioindicators of anthropogenic influence in agroecosystems.
Cereal Res. Commun., 35(2): 297 - 300

CAGÁŇ, L. (2008): Metodika ochrany proti škodcom kukurice [Methods of insect pest control in maize]. Nitra, Slovak agricultural university, $93 \mathrm{pp}$. (In Slovak)

DraKe, W. L., JordAN, D. L., SCHROEDER-MORENO, M., Johnson, P. D., Heitman, J. L., CARdoza, Y. J., Brandenburg, R. L., Shew, B. B., Corbett, T., Bogle, C. R., YE, W., HARDY, D. (2010): Crop Response following Tall Fescue Sod and Agronomic Crops. Agron. J., 102(6): 1692 - 1699. DOI: 10.2134/agronj2010.0236

FAO: Clothianidin (2010): Retrieved from http://www. fao.org/fileadmin/templates/agphome/documents/

Pests_Pesticides/Specs/Clothianidin2010.pdf online.

Ferris, H., Bongers, T., DE Goede, R. G. M. (2001): A framework for soil food web diagnostics. extension of the nematode faunal analysis concept. Appl. Soil Ecol., 18(1): 13 - 29. DOI: 10.1016/S0929-1393(01)00152-4

Freckman, D. W., EtTema, C. H. (1993): Assessing nematode communities in agroecosystems of varying human intervention. Agric. Ecosyst. Environ., 45(3 - 4): 239 - 261. DOI: 10.1016/0167-8809(93)90074-Y

JinGNAN, Z., QI, L., WENJU, L. (2010): Effect of acetochlor and carbofuran on soil nematode comunities in a Chinese soybean field. Afr. J. Agric. Res., 5(20): 2787 2794

Khan, A., Shaukat, S. S., Nawab, B., Khanzada, K. A., SolANGI, M. S. (2009): Management of nematodes associated with maize (Zea mays L.) using organic and inorganic amendments. Pakistan J. Agric. Res., 22(3 - 4): 165 - 167 Kimenju, J. W., Karanja, N. K., Mutua, G. K., Rimberia, B. M., WaChirA, P. M. (2009): Nematode community structure as influenced by land use and intensity of cultivation. Trop. Subtrop. Agroeco., 11(2): $353-360$

LANDI, S., MANACHINI, B. (2005): Nematodes associated with the rhizosphere of corn (Zea mays L.). Commun. Agric. Appl. Biol. Sci., 70(4): 937 - 944

LIŠKOVÁ, M., RENČO, M. (2007): Communities of free living and plant parasitic nematodes in hop gardens in Slovak Republic. Helminthologia. 44(2): 80 - 86. DOI: 10.2478/s1 1687-007-0008-6

MAnAChini, B., CoRsini, A., Bocchi, S. (2009): Soil Quality Indicators as Affected by a Long Term BarleyMaize and Maize Cropping Systems. Ital. J. Agron., 4(1): $15-22$

MANACHINI, B., LozZIA, G. C. (2002): First investigations into the effects of $\mathrm{Bt}$ corn crop on Nematofauna. Boll. Zool. Agraria e di Bachicoltura., 34, 85 - 96

McIntosh, P. D., Gibson, R. S., SAgGar, S., Yeates, G. W., MCGimpsey, P. (1999): Effect of contrasting farm management on vegetation and biochemical, chemical, and biological condition of moist steepland soils of the South Island high country, New Zealand. Austral. J. Soil Res., 37(5): $847-865$

MiKLÓS, L. (2002): Landscape atlas of the Slovak Republic. Bratislava. Ministry of Environment of the Slovak Republic, Slovak Environmental Agency, Banská Bystrica. 344 pp. 
NiShimATSU, T., JACKSON, J. J. (1998): Interaction of Insecticides, Entomopathogenic Nematodes, and Larvae of the Western Corn Root worm (Coleoptera. Chrysomelidae). J. Econ. Ent., 91(2): 410 - 418

Ou, W., Liang, W., Jiang, Y., Li, Q., Wen, D. (2005): Vertical distribution of soil nematodes under different land use types in an aquic brown soil. Pedobiologia, 49(2): 139 - 148. DOI: 10.1016/j.pedobi.2004.10.001

Pilz, C., Keller, S., Kuhlmann, U., Toepfer, S. (2009): Comparative efficacy assessment of fungi, nematodes and insecticides to control western corn rootworm larvae in maize. BioControl. 54: 671 - 684. DOI 10.1007/s10526009-9209-х

Rahman, L., Chan, K. Y., HeEnan, D. P. (2007): Impact of tillage, stubble management and crop rotation on nematode populations in a long-term field experiment. Soil Till. Res., 95(1 - 2): 110 - 119. DOI: 10.1016/j.still.2006.11.008

SABOVÁ, M., VAlOCKÁ, B., LišKovÁ, M. (1979): Species of corn crop nematodes and their seasonal dynamics. Helminthologia. 16(1): 35 - 44

SCHMUCK, R., KEPPLER, J. (2003): Clothianidin - Ecotoxicological profile and risk assessment. Pflanzenschutz-Nachrichten Bayer, 56: 26 - 58

ShannON, C. E., WeAver, W. (1949): The Mathematical Theory of Communication. Urbana, University of Illinois Press, $117 \mathrm{pp}$.

SouTHEY, J. F. (1986): Laboratory Methods for Work with Plant and Soil Nematodes. London, Her Majesty's Stationery Office, $202 \mathrm{pp}$.

STATSOFT, InC, (2001): STATISTICA Cz Software system for data analysis, Release 6, www.statsoft.cz

ŠÁLY, A. (1970): Nematodofauna of cultivated soils in the area of Zemplínska Š́rava water basin. (In Slovak). Acta Rer. Natur. Mus. Nat. Slov., 16(2): $9-17$

Š́́lY, A. (1976): Fauna of soil nematodes in the water work Region Liptovská Mara. Acta Zool. Univ. Comen., 20: 5 - 21 (In Slovak)

ŠÁly, A. (1983): Free-living nematodes in the Slovak Socialist Republic. Bratislava, VEDA Publishing House of the Slovak Academy of Sciences, 160 pp. (In Slovak)

TOEPfER, S., KuHLMAnN, U. (2004): Survey for natural enemies of the invasive alien chrysomelid, Diabrotica virgifera virgifera, in Central Europe. BioControl., 49(4): 385 - 395. DOI: 10.1023/B:BICO.0000034604.30847.44
Tylka, G. L., Sisson, A. J., Jesse, L. C., Kennicker, J., MARETT, C. C. (2011): Testing for Plant-parasitic Nematodes that Feed on Corn in Iowa 2000 - 2010. Online. Plant Health Progres. DOI: 10.1094/PHP-20111205-01-RS

Venette, R. C., FERris, H. (1997): Thermal constraints to population growth of bacterial-feeding nematodes. Soil Biol. and Biochem., 29(1): 63 - 74

Villenave, C., Rabary, B., Chotte, J. L., Blanchart, E., DJIGAL, D. (2009): Impact of direct seeding mulchbased cropping systems on soil nematodes in a long-term experiment in Madagascar. Pesq. Agropec. bras., 44(8): 949 - 953. DOI:10.1590/S0100-204X2009000800022

Voeste, D., Haden, E., Oloumi-Sadeghi, H. (2010): Pesticidal mixtures comprising phenysemicarbazone and clothianidin. US Patent Application Publication, Pub. No. US 2010/0093532 A1

WASILEWSKA, L. (1997): Soil invertebrates as bioindicators, with special reference to soil-inhabiting nematodes. Russ. J. Nematol., 5(2): 113 - 126

Waliyar, F., Ndunguru, B. J., Sharma, S. B., Bationo, A. (1992): Effect of liming and carbofuran on groundnut yield in sandy soils in Niger. Fertil. Res., 33(3): $203-208$ WiLliams, T. D., BEANE, J. (1984): Effects of aldicarb and benomyl on nematodes vesicular arbuscular mycorrhizas and the growth and yield of forage maize. Ann. Appl. Biol., 105(2): 245 - 252. DOI: $10.1111 / \mathrm{j} .1744-7348.1984 . t b 030$ 48.x

Yeates, G. W., Bongers, T., De Goede, R. G. M., FreckMAN, D. W., GeOrgieVA, S. S. (1993): Feeding habits in soil nematode families and genera - an outline for soil ecologists. J. Nematol., 25(3): 315 - 331

Yeates, G. W., Saggar, S., Hedley, C. B., Mercer, C. F. (1999): Increase in ${ }^{14} \mathrm{C}$-carbon translocation to the soil microbial biomass when five species of plant-parasitic nematodes infect roots of white clover. Nematology, 1(3): 295 - 300. DOI: 10.1163/156854199508298

ZHANG, J., QI, L., LIANG, W. (2010): Effect of acetochlor and carbofuran on soil nematode communities in a Chinese soybean field. Afr. J. Agric. Res., 5(20): 2787 - 2794

Zhou, J., Tao, J., Chen, X., Hu, F., LI, H. (2008): Soil nematode density inside and outside a pesticide factory in Anhui. Shengwu Duoyangxing, 16(6): 613 - 617. DOI: 10.3724/SP.J.1003.2008.08128 